\title{
Microclimatic studies in Paranhos water galleries, Porto (Portugal)
}

\author{
E. Sanz-Rubio \& A. Sanchez-Malo \\ Geomnia Natural Resources SLNE, Madrid, Spain
}

\author{
A. Fernandez-Cortes, E. Garcia-Anton \& S. Sanchez-Moral \\ Museo Nacional de Ciencias Naturales, MNCN-CSIC, Madrid, Spain \\ S. Cuezva \\ Universidad de Alicante, Alicante, Spain
}

\author{
A.Z. Miller \& A. Dionísio \\ Centro de Petrologia e Geoquímica/CERENA, Instituto Superior Técnico, Universidade Técnica de \\ Lisboa, Portugal
}

\author{
M. J. Afonso \& H. I. Chaminé \\ Instituto Superior de Engenharia do Porto, Portugal \\ B. Hermosin \& Cesareo Saiz-Jimenez \\ Instituto de Recursos Naturales y Agrobiologia, IRNAS-CSIC, Sevilla, Spain
}

\begin{abstract}
Paranhos constitutes one of the main water galleries excavated in the granite substratum of Porto City (Portugal) to gather the groundwater for public use during the past six centuries. The interest of this water gallery is double: a) Cultural Heritage and scientific value, b) Underground geoturism. A multidisciplinary research to study the microclimatology, geochemistry, mineralogy and geomicrobiology of the Paranhos catchwork galleries is currently in progress. The characterization of the main environmental parameters (air-rock temperature, relative humidity, $\mathrm{CO}_{2},{ }^{222} \mathrm{Rn}$, etc.) in the internal atmosphere would allow the establishment of: a) Fluid-rock interactions and development of a physical-chemical model of air-water-rock, as a base to define their relations with unusual mineral formations and microbial communities b)Microclimatic parameters and determination of effective radioactive dose for visitors based on

${ }^{222} \mathrm{Rn}$ studies, as potential use as underground geotourism site under safe conditions.
\end{abstract}

\section{INTRODUCTION}

The regional framework of Porto area consists of a crystalline fissured basement complex composed of highly deformed and overthrusted Late Proterozoic/Paleozoic metasediments and granitic rocks (Chaminé et al. 2010). For more than six centuries, water was supplied to Porto City through fountains fed by numerous springs. Paranhos and Salgueiros Spring galleries catchworks (3.2 km long) were excavated in the granite substratum of the city to gather the groundwater for public use to Porto inhabitants (Fig. 1). Paranhos is one of the main water galleries excavated in the crystalline bedrock, moderately deformed granitic rocks, randomly crossed by aplitic/pegmatitic veins. Our study is focused in the sector between St. Dinis and Burgães street entrances reaching a total length of 910 m divided in three segments. St. Dinis is the shallower entrance (higher altitude), where overburden is minimum. Ventilation shafts are located in many sectors of the gallery. The tunnel has an internal diameter of 2,20m and a maximum cover of 21 $\mathrm{m}$ and a minimum of $1 \mathrm{~m}$.

Paranhos spring supplies shallow groundwater that responds quickly to precipitation events, being particularly vulnerable to contamination, especially nitrates and sulphates (Afonso et al. 2006). However, the aquifer presents a low natural recharge due to the low permeability of the overlying urban area. Although groundwater is not more used for human consumption, other potential interests of the Paranhos gallery are currently evaluated: 


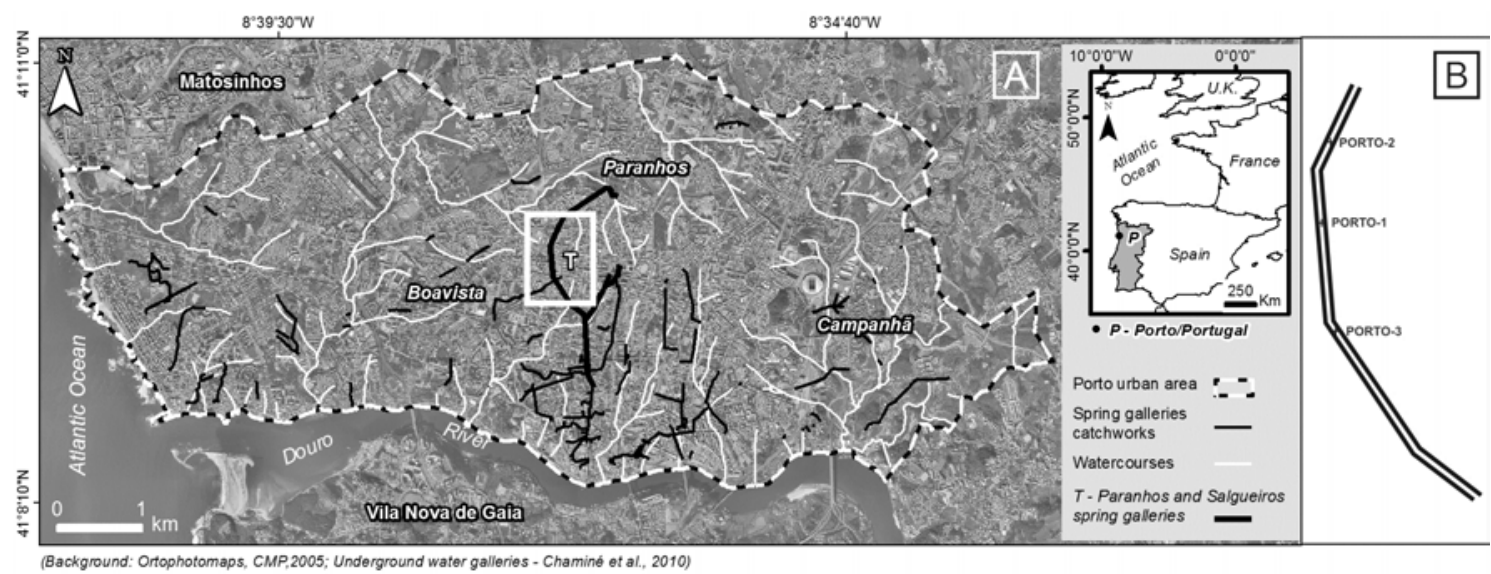

Figure 1. A). Geographical location of the Paranhos and Salgueiros Spring galleries. Modified from Chaminé et al. (2010). B) Sketch of the studied section of the tunnel that corresponds to white square in Figure 1A, showing three microclimatic stations.

a) Cultural Heritage and scientific value; aquifer vulnerability, urban speleological mapping and geo-engineering studies have been developed in the Paranhos galleries, but other scientific values can be remarked as the presence of unusual mineral formations (Sanchez-Moral et al. 2011) (e.g. Evansite) and microbial communities. Evansite comprise microlayers of amorphous hydrous aluminum-phosphate phases $\left.\mathrm{Al}_{2}\left(\mathrm{PO}_{4}\right)_{3}-5 . \mathrm{nH}_{2} \mathrm{O}\right)$ together with hydrolyzed uranyl groups and hydroxide $\mathrm{UO}_{2}(\mathrm{OH})_{2}$ precipitates. The microbiological study of these environments represents an approach to the discovery of the large bacterial diversity, the understanding of the role and functioning of these microorganisms and their implications on the conservation of the geo-sites or their affinity to particular hydrological processes or supply of contaminants from the external soil. Recent scientific assessment revealed that biological activity played a major role in the development of these manganese oxides, specifically birnessite and todorokite (Miller et al. 2012).Additional interest is related to the conservation issues of geo-sites.

b) Underground geotourism; as economical resource to attract tourists and investment. Artificial and stable underground spaces such as aqueducts or water galleries can be suitable for underground geotourism, previous establishment of the safe conditions for visitors.

The aim of the current study is the characterization of the geochemical and microclimatic dynamics of the Paranhos water gallery with special emphasis on the study of exchange cycles of atmospheric $\mathrm{CO}_{2}$. Concerning the establishment of safe conditions for potential visitors, the study also deals about characterization of ${ }^{222} \mathrm{Rn}$ gas emanation from host rock granite and radioactive minerals.

\section{MATERIAL AND METHODS}

Three fixed microenvironmental sampling stations were established in the Paranhos gallery (Porto 1, 2 and 3, Figure 1B) allowing the continuous monitoring of next parameters of air: 1) Air temperature and relative humidity with HOBO Pro v2 and Tinytag Plus 2 data loggers; 2) $\mathrm{CO}_{2}$ concentration measured using a ELG-33 datalogger (CO2meter). This sensor is located in a permanent station (Porto 2). All parameters are registered every 1 hour and the records are downloaded every 3 months.Radon 3) Gas ${ }^{222} \mathrm{Rn}$ measured by passive integration method (3 months period) with Kodalpha Radon dosimeter (GT Analytic).

In order to characterize cave levels of $\mathrm{CO}_{2}, \delta^{13} \mathrm{CO}_{2}$ and $\mathrm{CH}_{4}$ several air samples are taken every six months in an established points network along the gallery. Samples were obtained by filling Tedlar air sampling bags with capacity of $1 \mathrm{~L}$ and analyzed afterwards in laboratory by using an optic spectrometer Picarro G2101-i. Isotopic relationship $\delta^{13} \mathrm{CO}_{2}$ is measured as a calculation from ${ }^{12} \mathrm{CO}_{2}$ and ${ }^{13} \mathrm{CO}_{2}$ concentrations analyzed by the spectral system. During the same campaign, a 24-48 hours test for radon gas is performed at Porto 2 station using a Radon gas detector Durridge, RAD7. 


\section{RESULTS AND DISCUSSION}

Monitoring period was initiated in February 2012. The 6 months period of microclimatic characterization in the Paranhos gallery is providing next data:

Air temperature and relative humidity: constant relative humidity values are near saturation (100\%). Porto 1 and 3 stations present high response to daily changes, but a temperate response to seasonal cycles. Porto 2 is characterized by an accumulative effect of air temperature that could be related to the higher topographic location acting as hot air trap (Fig. 2A).

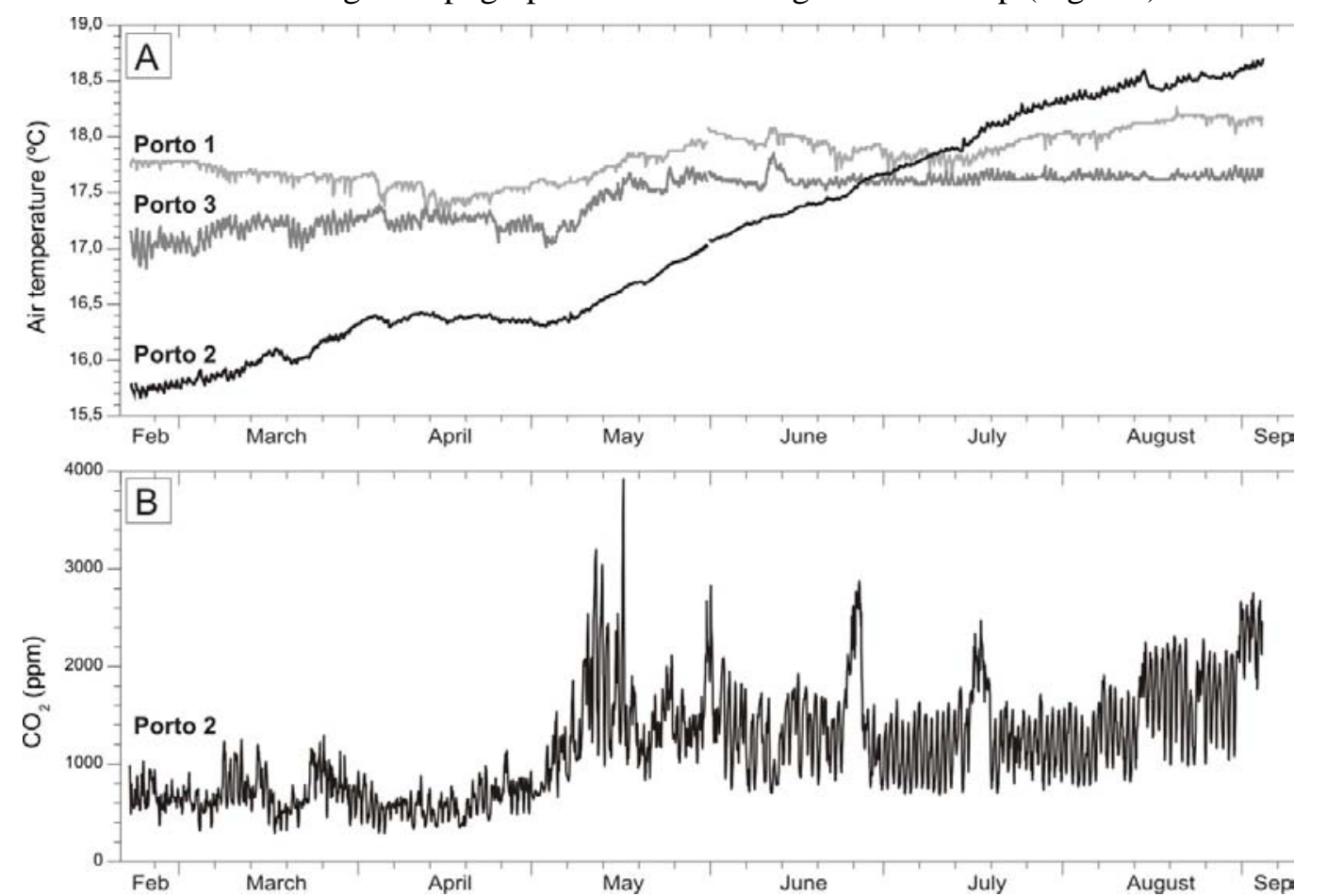

Figure 2. A) Temperature record in the three stations (Porto $1,2 \&$ 3). B) $\mathrm{CO}_{2}$ record in Porto 2 station.

$\mathrm{CO}_{2}$ : the low $\mathrm{CO}_{2}$ average concentration (around $700 \mathrm{ppm}$ ) of winter-spring period increased to $1,200 \mathrm{ppm}$ during late Spring-Summer; this effect can be interpreted as an indication of the summer reduction of the ventilation in the Porto 2 section (Fig. 2B).

${ }^{222} \mathrm{Rn}$ : radon gas is used as a quantitative index of ventilation in subterranean environments, but also it is fundamental for calculation of occupational dose of potential visitors. Passive Kodalpha detectors are indicating a clear seasonal increase of radon concentrations in Porto 3 from the winter-spring to summer season, and opposite pattern for Porto 2 (Table 1). A 48 hours test of continuous monitoring (30 minute data) in Porto 2 has also allowed the identification of this seasonal behavior, but also daily oscillations of coupled ${ }^{222} \mathrm{Rn}$ and $\mathrm{CO}_{2}$ (Fig. 3).

Table 1. Radon activity of air $\left.{ }^{222} \mathrm{Rn}, \mathrm{Bq} \cdot \mathrm{m}^{-3}\right)$ in the three stations.

\begin{tabular}{llll}
\hline Period & Porto 1 & Porto 2 & Porto 3 \\
\hline $21 / 02 / 2012-07 / 05 / 2012$ & $15992 \pm 1439$ & $18819 \pm 1506$ & $7528 \pm 678$ \\
$07 / 05 / 2012-26 / 07 / 2012$ & $12401 \pm 1868$ & $14049 \pm 983$ & $9131 \pm 639$ \\
$26 / 07 / 2012-06 / 09 / 2012$ & $18784 \pm 1315$ & $12749 \pm 892$ & $12951 \pm 907$ \\
\hline
\end{tabular}

Microenvironmental mapping from two campaigns (February and September 2012) for $\mathrm{CO}_{2}$, $\delta^{13} \mathrm{CO}_{2}$ and $\mathrm{CH}_{4}$ has allowed the observation of the spatial-seasonal variation of these parameters in the tunnel. This environment, as many caves, is characterized by relatively high levels of $\mathrm{CO}_{2}$ with very low $\delta^{13} \mathrm{C}$ isotopic signal values and low levels of $\mathrm{CH}_{4}$ compared with the external atmosphere. $\mathrm{CO}_{2}$ present in the internal atmosphere has a soil-derived origin. The highest $\mathrm{CO}_{2}$ concentrations, minimum $\mathrm{CH}_{4}$ and lighter isotopic values in both measured periods correspond 
to the Porto 2 section, although it is relatively close to the St. Dinis Entrance. This could be related to a relative isolation of the Porto 2 area respect the rest of the tunnel.

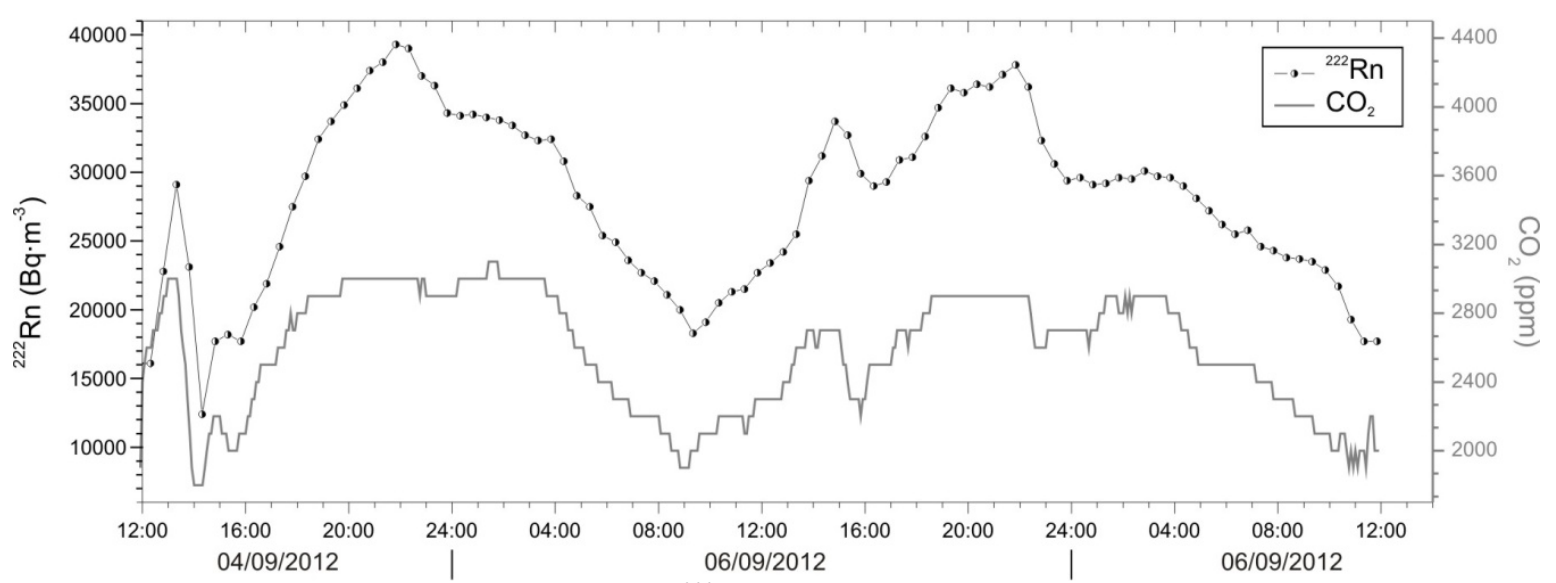

Figure 3. 48 hours continuous monitoring for ${ }^{222} \mathrm{Rn}$ and $\mathrm{CO}_{2}$ (Porto 2, early September 2012).

\section{CONCLUSIONS}

The six months period of environmental monitoring of the Paranhos gallery allowed the identification of the Porto 2 as the less ventilated sector of the tunnel by using microclimatic continuous monitoring (temperature, relative humidity and $\mathrm{CO}_{2}$ ) and mapping-interpretation of tunnel levels of $\mathrm{CO}_{2}, \delta^{13} \mathrm{CO}_{2}$ and $\mathrm{CH}_{4}$. Radon gas passive detectors also indicate the highest ${ }^{222} \mathrm{Rn}-$ activity of air in this area of the gallery, but an increase of ventilation rate towards the summer. The temperature records in Porto 2 indicate an accumulative effect probably due to the higher altitude, less forced ventilation via ventilation shafts and because the characteristics of the St. Dinis closure (hermetic door) and size of the tunnel. An opposite pattern is detected in the other extreme of gallery (Porto 3) and, to a lesser extent, in the middle of the gallery (Porto 1).

\section{ACKNOWLEDGEMENTS}

This research was supported by the Spanish Project CGL2011-25690.

\section{REFERENCES}

Afonso, M.J., Chaminé, H.I., Guimarães, L., Marques, J.M., Carreira, P., Paiva, C., Costa, I., Teixeira, J., Martins Carvalho, J., Guilhermino, L. \& Rocha, FT. 2006. Hydrochemical, ecotoxicological and isotopical approach from the Paranhos spring galleries catchworks from Porto urban area. In: Proceedings IWC2006: 213- 222. Porto: Centro de Estudos de Águas/IDT-ISEP.

Chaminé H.I., Afonso M.J., Robalo P.M., Rodrigues P., Cortez C., Monteiro Santos F.A., Plancha J.P., Fonseca P.E., Gomes A., Devy-Vareta N.F., Marques J.M., Lopes M.E., Fontes G., Pires A., \& Rocha, F. 2010. Urban speleology applied to groundwater and geo-engineering studies: underground topographic surveying of the ancient Arca D’Água galleries catchworks (Porto, NW Portugal). International Journal of Speleology 39: 1-14.

Miller, A.Z., Dionísio, A., Sequeira Braga, M.A., Hernández-Mariné, M., Afonso, M.J., Muralha, V.S.F., Herrera, L.K., Raabe, J., Fernandez-Cortes, A., Cuezva, S., Hermosin, B., Sanchez-Moral, S., Chaminé, H. \& Saiz-Jimenez, C. 2012. Biogenic Mn oxide minerals coating in a subsurface granite environment. Chemical Geology 322-323: 181-191.

Sanchez-Moral S., Fernandez-Cortes A., Cuezva S., Cañaveras J.C., Correcher V., Miller A.Z., Dionisio A., Marques J.M., Saiz-Jimenez C., Afonso M.J., Chaminé H.I., Furio M. \& Garcia-Guinea J. 2011. Uranyl-evansites from Porto (Northwest Portugal) and Galicia (Northwest Spain): Structure and Assignment of Spectra Catholuminescence and Raman Bands. Spectroscopy Letters 44: 511-515. 